Relations industrielles

Industrial Relations

\title{
The Shorter Work Week in Canada
}

Volume 13, numéro 1, janvier 1958

URI : https://id.erudit.org/iderudit/1022476ar

DOI : https://doi.org/10.7202/1022476ar

Aller au sommaire du numéro

Éditeur(s)

Département des relations industrielles de l’Université Laval

\section{ISSN}

0034-379X (imprimé)

1703-8138 (numérique)

Découvrir la revue

Citer ce document

(1958). The Shorter Work Week in Canada. Relations industrielles / Industrial Relations, 13(1), 105-105. https://doi.org/10.7202/1022476ar

Tous droits réservés (C Département des relations industrielles de l’Université Laval, 1958
Ce document est protégé par la loi sur le droit d'auteur. L'utilisation des services d'Érudit (y compris la reproduction) est assujettie à sa politique d'utilisation que vous pouvez consulter en ligne.

https://apropos.erudit.org/fr/usagers/politique-dutilisation/ 


\section{THE SHORTER WORK WEEK IN CANADA}

More than 64 per cent of office workers in the manufacturing industry were working a $371 / 2$-hour, or shorter, work week in April 1957, as compared with only 45.8 per cent in 1949 , according to information released at the end of November, 1957 by Hon. Michael Starr, Minister of Labour.

The Labour Department's annual survey of working conditions, which is conducted by the Economics and Research Branch, revealed this information. More than 90 per cent of the 225,000 office workers in manufacturing covered by the survey were on a 5-day week in April 1957 compared to 67.5 per cent in 1949 .

(Further details are contained in the November issue of the Labour Gazette.)

The survey showed that more than 75 per cent of the employees covered were in establishments which made provision for paid vacations of three weeks, usually after 15 years' service. A year ago the proportion of office employees receiving paid vacations of three weeks after 15 years' or less service was 62.4 per cent and the comparable figure in 1949 was only 10.3 per cent.

In 1957 as in 1956, eight paid statutory holidays was the most commonly granted number. However, there was a continuing increase in the proportion of office employees who received nine or more statutory holidays per year. In April 1957, 24.9 per cent of office employees were in the "nine, or more, statutory holidays" group compared with 20 per cent in 1954 and 16.9 per cent in 1949.

Group life insurance was available to 93.5 per cent of the office workers covered by the survey compared to 90.5 per cent in 1956 and 87.4 per cent in 1954. Pension plans were available to 81.3 per cent of the office workers covered in 1957 compared with 78.4 per cent in 1956 and 71.7 per cent in 1954 .

The percentage of plant employees in the manufacturing industry on a 5-day week had risen to 88.4 per cent of all plant employees in the industry by April 1957, as compared with 85.5 per cent in April 1956 and 82.5 per cent in 1954.

This information was brought out as a result of the 1957 annual survey of working conditions conducted by the Labour Department's Economics and Research Branch. The survey covered some 6,100 establishments employing about 805,000 plant and 225,000 office employees.

The survey also established that the rise in the proportion of plant workers on a 40-hour week had been quite marked reaching about two-thirds of all plant employees in April 1957. Three years ago only about half the workers covered were on a 40 -hour week.

Two-weeks' vacation with pay was reported by establishments employing 95 per cent of the plant workers covered by the survey. Service requirements for a second week of vacation had not changed much in recent years, three to five years service being the usual requirements. This year's survey, however, revealed a slight increase in the proportion of workers who can receive two weeks paid vacation after one year's service.

Significant changes in the incidence of paid statutory holidays were also shown by the 1957 survey. The proportion of workers receiving eight or more paid holidays was more than two-thirds, compared with about half three years ago. About 14 per cent of plant workers received nine or more paid statutory holidays per year in 1957 compared to 8.6 per cent in 1954 . 